\title{
Delayed diagnosis of tuberculosis: risk factors and effect on mortality among older adults in Hong Kong
}

\author{
Eric CC Leung *, CC Leung, KC Chang, CK Chan, Thomas YW Mok, KS Chan, KS Lau, CH Chau, \\ Wilson KS Yee, WS Law, SN Lee, KF Au, LB Tai, WM Leung
}

\section{A B S T R A C T}

Objective: To assess the risk factors and effects of delayed diagnosis on tuberculosis (TB) mortality in Hong Kong.

Methods: All consecutive patients with TB notified in 2010 were tracked through their clinical records for treatment outcome until 2012. All TB cases notified or confirmed after death were identified for a mortality survey on the timing and causes of death.

Results: Of 5092 TB cases notified, 1061 (20.9\%) died within 2 years of notification; 211 (4.1\%) patients died before notification, 683 (13.4\%) died within the first year, and 167 (3.3\%) died within the second year after notification. Among the 211 cases with TB notified after death, only 30 were certified to have died from TB. However, 52 (24.6\%) died from unspecified pneumonia/sepsis possibly related to pulmonary TB. If these cases are counted, the total TB-related deaths increases from 191 to 243. In $82(33.7 \%)$ of these, TB was notified after death. Over $60 \%$ of cases in which TB was diagnosed after death involved patients aged $\geq 80$ years and a similar proportion had an advance care directive against resuscitation or investigation. Independent factors for TB notified after death included female sex, living in an old age home, drug abuse, malignancy other than lung cancer, sputum TB smear negative, sputum TB culture positive, and chest X-ray not done.

This article was published on $30 \mathrm{Jul}$ 2018 at www.hkmj.org.
Conclusions: High mortality was observed among patients with TB aged $\geq 80$ years. Increased vigilance is warranted to avoid delayed diagnosis and reduce the transmission risk, especially among elderly patients with co-morbidities living in old age homes.

Hong Kong Med J 2018;24:361-8 DOI: $10.12809 / \mathrm{hkmj} 177081$

\section{${ }^{1}$ ECC Leung *, MB, BS, FHKAM (Medicine) \\ ${ }^{1}$ CC Leung, MB, BS, FHKAM (Medicine) \\ ${ }^{1}$ KC Chang, MB, BS, FHKAM (Medicine) \\ ${ }^{1}$ CK Chan, MB, BS, FHKAM (Medicine) \\ ${ }^{2}$ TYW Mok, MB, BS, FHKAM (Medicine) \\ ${ }^{3}$ KS Chan, MB, BS, FHKAM (Medicine) \\ ${ }^{4}$ KS Lau, MB, BS, FHKAM (Medicine) \\ ${ }^{5}$ CH Chau, MB, BS, FHKAM (Medicine) \\ ${ }^{6}$ WKS Yee, MB, ChB, FHKAM (Medicine) \\ ${ }^{1}$ WS Law, MB, ChB, FHKAM (Medicine) \\ ${ }^{1}$ SN Lee, MB, ChB, FHKAM (Medicine) \\ ${ }^{1} \mathrm{KF} \mathrm{Au}, \mathrm{MB}, \mathrm{ChB}, \mathrm{MRCP}(\mathrm{UK})$ \\ ${ }^{1}$ LB Tai, MB, ChB, FHKAM (Medicine) \\ ${ }^{1}$ WM Leung, MB, ChB, FHKAM (Medicine)}

1 Tuberculosis and Chest Service, Centre for Health Protection, Department of Health, Hong Kong

Respiratory Medicine Department, Kowloon Hospital, Homantin, Hong Kong

3 Pulmonary Service, Department of Medicine, Haven of Hope Hospital, Tseung Kwan O, Hong Kong

${ }^{4}$ Respiratory Medicine Department, Ruttonjee Hospital, Wanchai, Hong Kong

5 Tuberculosis and Chest Unit, Grantham Hospital, Wong Chuk Hang, Hong Kong

${ }^{6}$ Department of Medicine and Geriatrics, Kwong Wah Hospital, Hong Kong

* Corresponding author: eric_leung@dh.gov.hk

\footnotetext{
New knowledge added by this study

- Mortality among elderly patients with tuberculosis (TB) in Hong Kong is high.

- There is a risk of institutional TB transmission because a substantial portion (42\%) of these elderly people live in old age homes.

- Timely diagnosis and treatment of TB is necessary to avert adverse outcomes and prevent transmission.

Implications for clinical practice or policy

- Increased vigilance and deployment of rapid diagnostic tools are necessary to facilitate early diagnosis of TB and to reduce the TB transmission risk, especially among elderly patients with co-morbidities living in old age homes.
}

\section{Introduction}

Over the past 30 years, the proportion of the Hong Kong population aged $\geq 65$ years doubled from $6.6 \%$ in 1981 to $13.3 \%$ in $2011 .{ }^{1}$ The proportion of those aged $\geq 65$ years among patients with tuberculosis (TB) tripled from $13 \%^{2}$ to $39 \%^{3}$ in the same period. Although the annual notification rate decreased from 149.1 to 65 per 100000 population and the TB 


\section{結核病的延遲診斷：其風險因素及對香港老年人 死亡率的影響 \\ 梁中正、梁子超、鄭國釗、陳志權、莫恩榮、陳健生、 劉錦城、周志雄、易國生、羅穎思、李淑娜、區家輝、 戴麗文、梁偉民 \\ 目的：研究未能適時診斷結核病的風險因素及評估其對香港結核病死 亡率的影響。}

方法：從2010年所有連續呈報的結核病患者的醫療紀錄, 追踪直至 2012年的治療結果。鑒別所有在死亡後呈報或確認的結核病病例, 進 行死亡時間和原因的研究。

結果：在呈報的5092宗結核病病例中, 共1061名患者 (20.9\%) 在結 核病呈報兩年內死亡; 其中211名患者 $(4.1 \%$ ) 在呈報前死亡, 683名 患者 $(13.4 \%)$ 在呈報後的一年內死亡, 167 名患者 $(3.3 \%)$ 在呈報後 第二年內死亡。在上述 211 宗死亡後才獲呈報的結核病病例中, 只有 30 宗病例核證的死亡原因為結核病, 另外 52 宗病例 $(24.6 \%)$ 死於可 能與肺結核相關的非特定肺炎/敗血症。若加上這些病例, 與結核病 相關的死亡病例總數則從 191增至243宗。其中 82 宗病例 $(33.7 \%$ ) 的 結核病是患者死亡後呈報。超過 $60 \%$ 在死亡後結核病才獲診斷的患者 年齡皆為 80 歲以上, 而相若比率的患者預設醫療指示表明不希望施行 心肺復更生或醫療檢驗。女性病人、居於安老院院舍、濫用藥物、肺腫 瘤以外的癌症、痰結核塗陰性、痰結核培陽性和沒有進行肺部X光造 影檢驗皆為結核病在患者死亡後才獲呈報的獨立風險因素。

結論：80歲以上的結核病患者死亡率偏高, 有必要提高警覺, 以避免 出現結核病未能被適時診斷的情況, 從而減低傳播風險。其中以居於 安老院院舍的老年病者及患有其他長期病患的病者尤為重要。 mortality rate decreased from 9.4 to 2.6 per 100000 population from 1981 to 2011, the proportion of those aged $\geq 65$ years increased from $53 \%$ to $82 \%$ among TB deaths. ${ }^{2,3}$ In older adults, TB is associated with other co-morbidities, hospitalisation, and delays in presentation and commencement of treatment. ${ }^{4}$ Missed opportunities for intervention might contribute to the higher mortality rates in older adults, and might also increase the risk of TB transmission. The present longitudinal study was conducted to assess the effects of age on the mortality rates of patients with $\mathrm{TB}$ and to elucidate the factors associated with missed TB diagnosis.

\section{Methods}

All consecutive cases of TB notified to the Department of Health in 2010 were retrospectively collected from the statutory TB notification registry. Hong Kong identity card numbers (or passport numbers for non-residents) were retrieved from the notification registry, together with date of notification, source of notification, and demographic and clinical information. Further clinical information and outcome data at 1 year after notification/initiation of treatment were retrieved from the TB programme record forms. ${ }^{3}$ These forms are filed by the TB and Chest Service for patients managed under its chest clinics and for patients managed by other health care providers. Treatment outcome was classified according to the World Health Organization (WHO) recommendations. ${ }^{5}$ Using the identity card number/ passport number as the unique identifier, the 2010 TB cohort data were cross-matched with the statutory death registry from 1 January 2009 till 31 December 2012 for vital status, date and cause(s) of death. All cases with a date of TB notification after the date of death were recorded. A mortality survey was conducted on these recorded cases by retrieving relevant clinical information from records in public clinics and hospitals.

The demographics, co-morbidities, treatment outcomes, and mortality pattern of the cohort were analysed. Published data on patients of all ages with $\mathrm{TB}^{6}$ and on elderly patients with $\mathrm{TB}^{7}$ notified in 1996 were used for comparison. A date of TB notification after the date of death was considered as a surrogate marker of delayed diagnosis. Categorical variables were analysed by Pearson $\chi^{2}$ test or Fisher's exact test as appropriate; continuous variables were analysed by Mann-Whitney $U$ test. Binary regression modelling was used to calculate the adjusted odds ratios (aORs) for risk factors for delayed diagnosis of $\mathrm{TB}$ after death using a backward conditional approach, with probability to remove being 0.10 and to retain being 0.05 . A two-tailed $\mathrm{P}<0.05$ was considered statistically significant. Statistical analyses were performed using SPSS for Windows, version 16.0 (SPSS Inc, Chicago [IL], US).

\section{Results}

After exclusion of 336 cases subsequently denotified because of alternative diagnoses, a total of 5092 patients with TB were included in the 2010 TB cohort, at a notification rate of 72.5/100000 personyears. Table 1 summarises their demographic data, clinical characteristics, and 1-year outcomes. Comparison with published data on the 1996 TB cohort $^{6,7}$ was restricted to patients managed under the TB and Chest Service, for which the proportion of patients with TB aged $\geq 60$ years increased from $34.5 \%$ in 1996 to $42.9 \%$ in 2010 . There were more co-morbidities such as diabetes mellitus (16.0\% vs $9.6 \%)$, lung cancer $(2.1 \%$ vs $1.1 \%)$, and other cancers $(5.0 \%$ vs $0.6 \%)$ in the $2010 \mathrm{~TB}$ cohort than in the 1996 TB cohort ( $X^{2}$ test, $\left.\mathrm{P}<0.001\right)$. In 2010, the proportion of patients who died before completion of TB treatment was smaller for those managed under the TB and Chest Service (7.4\%) than for the overall cohort (16.2\%). However, the proportion of patients managed under the TB and Chest Service who died before completion of TB treatment nearly doubled between 1996 (3.9\%) and 2010 (7.4\%).

Among 5092 TB notifications, 1061 (20.9\%) 
TABLE I. Demographic profile, clinical characteristics, and I-year outcomes of the 2010 TB cohort* compared with published data on the I996 TB cohort $\dagger$

\begin{tabular}{|c|c|c|c|c|}
\hline & $\begin{array}{l}\text { All patients with TB } \\
\text { notified in } 2010\end{array}$ & $\begin{array}{c}2010 \text { TB cohort: } \\
\text { patients managed } \\
\text { by the TB and Chest } \\
\text { Service* }\end{array}$ & $\begin{array}{c}1996 \text { TB cohort: } \\
\text { patients managed } \\
\text { by the TB and Chest } \\
\text { Service } \\
\text { S,7 }\end{array}$ & $\begin{array}{l}\text { OR }(95 \% \mathrm{Cl}), \mathrm{P} \\
\text { valuet, } \chi^{2}\end{array}$ \\
\hline Total No. of patients & 5092 & 4111 & 5757 & - \\
\hline Female sex & $1863(36.6 \%)$ & $1496(36.4 \%)$ & $1778(30.9 \%)$ & $0.78(0.72-0.85)$ \\
\hline \multicolumn{5}{|l|}{ Age-group (years) } \\
\hline $0-19$ & $179(3.5 \%)$ & $158(3.8 \%)$ & $309(5.4 \%)$ & $\chi^{2}=159.48$ \\
\hline $20-39$ & $1111(21.8 \%)$ & $952(23.2 \%)$ & 1942 (33.7\%) & $P<0.001$ \\
\hline $40-59$ & $1414(27.8 \%)$ & $1237(30.1 \%)$ & $1519(26.4 \%)$ & \\
\hline$\geq 60$ & 2388 (46.9\%) & 1764 (42.9\%) & 1987 (34.5\%) & \\
\hline \multicolumn{5}{|l|}{ Type of cases } \\
\hline Pulmonary only & $3675(72.2 \%)$ & $2883(70.1 \%)$ & $4474(77.7 \%)$ & $\chi^{2}=82.43$ \\
\hline Extrapulmonary & $854(16.8 \%)$ & $682(16.6 \%)$ & $790(13.7 \%)$ & $P<0.001$ \\
\hline Both & $563(11.1 \%)$ & $546(13.3 \%)$ & $493(8.6 \%)$ & \\
\hline Positive TB smear & $1698(33.3 \%)$ & $1436(34.9 \%)$ & $1628(28.3 \%)$ & $1.36(1.25-1.49)$ \\
\hline Positive TB culture & 2932 (57.6\%) & 2415 (58.7\%) & 2968 (51.6\%) & $1.34(1.23-1.45)$ \\
\hline \multicolumn{5}{|l|}{ Outcome at 12 months } \\
\hline Cured or Tx completed $\ddagger$ & 3405 (66.9\%) & $3070(74.7 \%)$ & 4628 (80.4\%) & $\chi^{2}=282.8$ \\
\hline Still on Tx & $463(9.1 \%)$ & $446(10.8 \%)$ & $238(4.1 \%)$ & $\mathrm{P}<0.001$ \\
\hline Died§ & $823(16.2 \%)$ & $303(7.4 \%)$ & 222 (3.9\%) & \\
\hline Transferred & 177 (3.5\%) & $120(2.9 \%)$ & 209 (3.6\%) & \\
\hline Defaulted Tx & 220 (4.3\%) & $168(4.1 \%)$ & $460(8.0 \%)$ & \\
\hline Others & $4(0.1 \%)$ & $4(0.1 \%)$ & 0 & \\
\hline Co-morbidities & & & & All $P<0.001$ \\
\hline Diabetes & 719 (14.1\%) & $656(16.0 \%)$ & 555 (9.6\%) & $1.78(1.58-2.01)$ \\
\hline Silicosis & $16(0.3 \%)$ & $15(0.4 \%)$ & $84(1.5 \%)$ & $0.25(0.14-0.44)$ \\
\hline Lung cancer & $128(2.5 \%)$ & $88(2.1 \%)$ & $62(1.1 \%)$ & $2.01(1.43-2.82)$ \\
\hline Other cancers & $276(5.4 \%)$ & 206 (5.0\%) & $32(0.6 \%)$ & $9.44(6.40-13.99)$ \\
\hline HIV infection & $30(0.6 \%)$ & $24(0.6 \%)$ & $6(0.1 \%)$ & $5.63(2.19-15.37)$ \\
\hline Chronic renal failure & $112(2.2 \%)$ & $69(1.7 \%)$ & NA & - \\
\hline Living in old age home with multiple disabilities & $390(7.7 \%)$ & $292(7.1 \%)$ & NA & - \\
\hline
\end{tabular}

Abbreviations: $\mathrm{Cl}=$ confidence interval; HIV = human immunodeficiency virus; $\mathrm{NA}=$ not available; $\mathrm{OR}=$ odds ratio; TB = tuberculosis; Tx = treatment

* Excluding 919 patients who were not managed under the TB and Chest Service

+ Comparison between 2010 and 1996 TB cohorts was restricted to patients with TB managed by TB and Chest Service

‡ Cured or having completed treatment irrespective of subsequent death, default, or relapse before the end of I year

$\S$ Died before treatment completion (7I patients who died after completion of treatment were excluded)

deaths occurred within 2 years of notification. Of the 1061 deaths, 211 (4.1\%) occurred before the TB notification (ie, TB was notified after death; median delay in notification [interval between death and TB notification] 45 days, interquartile range 30-65 days). Of the deaths after notification, 683 (13.4\%) died in the first year and 167 (3.3\%) died in the second year. The reported causes of death were related to TB in only $191(18.0 \%)$ of all deaths; $30(14.2 \%)$ before TB notification, $158(23.1 \%)$ in the first year, and three $(1.8 \%)$ in the second year after notification.
Among the 211 deaths before TB notification, only $30(14.2 \%)$ had TB as the main cause of death. There were 54 cases of 'pneumonia unspecified' and three cases of 'sepsis unspecified' reported as main cause of death. Of these cases, only five with potential causative organisms, such as Pseudomonas, Acinetobacter, or Escherichia coli, were identified. However, in the sputum that had been collected before death in these patients, Mycobacterium tuberculosis was subsequently isolated after prolonged culture, indicating that TB was the likely main cause of 
death in the remaining 52 deaths initially reported as 'sepsis or pneumonia unspecified'. Including these revised results increases the 2010 TB-related mortality from 191 to 243 , ie, an increase of $27 \%$ from the officially reported mortality figures of 2.6 to 3.4 per 100000 person-years. ${ }^{8}$ The corresponding proportion of TB-related mortality increases to $38.8 \%(82 / 211)$ in cases with TB notified after death compared with $23.3 \%$ (158/683) who died in the first year after notification and $1.7 \%(3 / 167)$ who died in the second year. Therefore, a substantial proportion (15.5\%) of TB-related deaths could potentially have been prevented by early diagnosis and treatment.

For the 211 deaths before TB notification, 25 cases of TB were notified from the public mortuary. Of the remaining 186 cases of TB that were notified from hospital, 173 hospital records were collected; 13 cases had missing data. None of the 198 patients with retrievable records were started on treatment. Of these 198 patients, 119 (60.1\%) were aged $\geq 80$ years at the time of death, and 93 (47\%) had more than one admission to hospital before death. Prior to death, of these 198 patients, 83 (41.9\%) were living in an old age home (OAH), 78 (39.4\%) were bed-ridden, and $121(61.1 \%)$ had an advance care directive such as 'do not resuscitate' or 'do not investigate' stated in the case notes. Table 2 summarises the univariate and multiple logistic regression analyses of these 198 early deaths, using deaths occurring within 1 year after notification as controls. Female sex, having a malignancy other than lung cancer, living in an $\mathrm{OAH}$, drug abuser, sputum TB smear negative, sputum TB culture positive, and chest X-ray (CXR) not done or not available were independent risk factors for death before TB diagnosis.

Subgroup analysis was carried out for patients that most likely died of TB. The study group included the 30 patients who died of TB before diagnosis and the 52 patients whose deaths were initially reported as 'sepsis or pneumonia unspecified' but later sputum TB culture was positive. The control group was all patients who died of TB after notification (Table 3). Female sex, living in an OAH, sputum TB smear negative, sputum TB culture positive, and CXR not done or not available were independent risk factors for this group.

TABLE 2. Univariate and multiple logistic regression analyses of TB notified after death, using all deaths occurring within I year after notification as control

\begin{tabular}{lccccc}
\hline Covariate & $\begin{array}{c}\text { TB notified after } \\
\text { death (n=198)* }\end{array}$ & $\begin{array}{c}\text { All-cause mortality } \\
\text { within first year } \\
\text { after TB notification } \\
\text { (n=683) }\end{array}$ & $\begin{array}{c}\text { P value } \\
\left.\text { (by } \chi^{2}\right)\end{array}$ & OR (95\% Cl) & aOR (95\% Cl)† \\
\hline Female sex & $69(34.8 \%)$ & $150(22.0 \%)$ & $<0.0001$ & $1.90(1.35-2.68)$ & $1.81(1.22-2.70)$ \\
\hline Age $\geq 80$ years & $119(60.1 \%)$ & $326(47.7 \%)$ & 0.002 & $1.65(1.20-2.28)$ & - \\
\hline DM & $47(23.7 \%)$ & $102(14.9 \%)$ & 0.004 & $1.77(1.20-2.6)$ & $1.55(0.99-2.43) \ddagger$ \\
\hline Lung cancer & $16(8.1 \%)$ & $78(11.4 \%)$ & 0.180 & $0.68(0.39-1.20)$ & - \\
\hline Other cancers & $43(21.7 \%)$ & $101(14.8 \%)$ & 0.020 & $1.60(1.08-2.38)$ & $1.80(1.14-2.85)$ \\
\hline Chronic renal failure & $16(8.1 \%)$ & $62(9.1 \%)$ & 0.664 & $0.88(0.49-1.56)$ & - \\
\hline Silicosis & $1(0.5 \%)$ & $1(0.1 \%)$ & $0.399 \S$ & $3.46(0.22-55.6)$ \\
\hline Drug abuse & $6(3.0 \%)$ & $5(0.7 \%)$ & 0.010 & $4.24(1.28-14.04)$ & $11.03(2.79-43.55)$ \\
\hline Previous gastrectomy & $1(0.5 \%)$ & $3(0.4 \%)$ & $1.000 \S$ & $1.05(0.12-11.12)$ \\
\hline HIV positive & $1(0.5 \%)$ & $2(0.3 \%)$ & $0.535 \S$ & $1.72(0.16-19.53)$ \\
\hline $\begin{array}{l}\text { Living in old age homes (due to old age, } \\
\text { immobility, stroke) }\end{array}$ & $83(41.9 \%)$ & $108(15.8 \%)$ & $<0.0001$ & $3.84(2.71-5.45)$ & $3.56(2.63-5.29)$ \\
\hline Old stroke & $35(17.7 \%)$ & $69(10.1 \%)$ & 0.004 & $1.91(1.23-2.97)$ \\
\hline Smear negative & $189(95.5 \%)$ & $435(63.7 \%)$ & $<0.001$ & $11.90(6.02-23.81)$ & $12.34(5.95-25.64)$ \\
\hline Culture positive & $144(72.7 \%)$ & $405(59.3 \%)$ & 0.001 & $1.83(1.29-2.59)$ & $4.02(2.51-6.42)$ \\
\hline CXR not taken or not available & $35(17.7 \%)$ & $64(9.4 \%)$ & 0.001 & $2.07(1.33-3.25)$ & $3.87(2.13-6.99)$ \\
\hline Abbres & & - & - \\
\hline
\end{tabular}

Abbreviations: $\mathrm{aOR}$ = adjusted odds ratio; $\mathrm{Cl}=$ confidence interval; $\mathrm{CXR}=$ chest $\mathrm{X}$-ray; $\mathrm{DM}$ = diabetes mellitus; $\mathrm{HIV}=$ human immunodeficiency virus; $\mathrm{OR}$

= odds ratio; $\mathrm{TB}=$ tuberculosis

* 13 Cases with missing data were excluded

† aOR in binary regression modelling using backward conditional approach, with probability to remove being 0.10 and to retain being 0.05

‡ $\mathrm{P}=0.053$

$\S$ Fisher's exact test 
TABLE 3. Subgroup analysis on patients died of TB before notification versus after notification

\begin{tabular}{|c|c|c|c|c|c|}
\hline Covariate & $\begin{array}{l}\text { TB as the likely } \\
\text { cause of death } \\
\text { before TB } \\
\text { notification }(n=82)^{*}\end{array}$ & $\begin{array}{c}\text { TB as main cause } \\
\text { of death after } \\
\text { TB notification } \\
(n=161)\end{array}$ & $\begin{array}{l}\text { P value } \\
\left.\text { (by } \chi^{2}\right)\end{array}$ & OR (95\% Cl) & aORt (95\% Cl) \\
\hline Female sex & $36(43.9 \%)$ & $35(21.7 \%)$ & $<0.0001$ & $2.82(1.58-5.00)$ & $2.44(1.16-5.17)$ \\
\hline Age $\geq 80$ years & $52(63.4 \%)$ & $86(53.4 \%)$ & 0.137 & $1.51(0.88-2.61)$ & - \\
\hline DM & $16(19.5 \%)$ & $16(9.9 \%)$ & 0.037 & $2.20(1.04-4.66)$ & - \\
\hline Lung cancer & $5(6.1 \%)$ & $3(1.9 \%)$ & 0.080 & $3.42(0.80-14.68)$ & $5.65(0.92-3.45)$ \\
\hline Other cancers & 7 (8.5\%) & $6(3.7 \%)$ & 0.115 & $2.41(0.78-7.43)$ & - \\
\hline Chronic renal failure & $5(6.1 \%)$ & $13(8.1 \%)$ & 0.578 & $0.74(0.25-2.15)$ & - \\
\hline Silicosis & 0 & 0 & NA & NA & - \\
\hline Drug abuse & $1(1.2 \%)$ & $4(2.5 \%)$ & $0.665 \ddagger$ & $0.49(0.05-4.41)$ & - \\
\hline Previous gastrectomy & 0 & 0 & NA & NA & - \\
\hline HIV positive & $1(1.2 \%)$ & $2(1.2 \%)$ & $1.00 \ddagger$ & $0.98(0.09-10.99)$ & - \\
\hline $\begin{array}{l}\text { Living in old age homes (due to old age, } \\
\text { immobility, stroke) }\end{array}$ & $34(41.5 \%)$ & $11(6.8 \%)$ & $<0.0001$ & $9.66(4.55-20.52)$ & $9.62(3.82-24.39)$ \\
\hline Old stroke & $14(17.1 \%)$ & $10(6.2 \%)$ & 0.007 & $3.11(1.32-7.35)$ & - \\
\hline Smear negative & $76(92.7 \%)$ & $92(57.1 \%)$ & 0.001 & $9.52(3.91-23.26)$ & $8.04(2.95-21.88)$ \\
\hline Culture positive & $60(73.2 \%)$ & $83(51.6 \%)$ & 0.001 & $2.56(1.44-4.57)$ & $8.77(3.38-22.73)$ \\
\hline CXR not taken or NA & $16(19.5 \%)$ & $16(9.9 \%)$ & 0.037 & $2.20(1.04-4.65)$ & $8.17(2.58-25.86)$ \\
\hline
\end{tabular}

Abbreviations: $\mathrm{aOR}=$ adjusted odds ratio; $\mathrm{Cl}=$ confidence interval; $\mathrm{CXR}=$ chest $\mathrm{X}$-ray; $\mathrm{DM}=$ diabetes mellitus; $\mathrm{HIV}=$ human immunodeficiency virus; $\mathrm{NA}$

$=$ not available; $\mathrm{OR}=$ odds ratio; $\mathrm{TB}=$ tuberculosis

* Including patients whose recorded cause of death was TB $(n=30)$ or unspecified pneumonia but later sputum TB culture positive $(n=52)$

† Adjusted odds ratio in binary regression modelling using backward conditional approach, with probability to remove being 0.10 and to retain being 0.05

‡ Fisher's exact test

\section{Discussion}

In the present study, the proportion of patients with TB aged $\geq 60$ years increased by $25 \%$ from 1996 to 2010. However, over the same interval, the proportion of patients who had died before completion of treatment nearly doubled (Table 1). A substantial proportion $(211$ of $1061 ; 19.9 \%)$ of the TB-related deaths were notified after death. Over $60 \%$ of these cases were aged $\geq 80$ years and none were started on treatment, suggesting a failure to detect TB rather than just a delay in notification. Over $60 \%$ of them had an advance care directive against resuscitation or investigation, likely indicating a concurrent terminal illness. Independent factors associated with TB notified after death were female sex, malignancies other than lung cancer, living in an $\mathrm{OAH}$, drug abuse, sputum $\mathrm{TB}$ smear negative, sputum TB culture positive, and CXR not done. Although the recorded cause of death was TB in only $30(14 \%)$ cases, in $52(25 \%)$ cases the recorded cause of death was respiratory disease (predominantly pneumonia unspecified), particularly among those aged $\geq 80$ years $(19 \%$ vs $39 \% ; P<0.005)$. In these cases, pulmonary TB is likely to have been the main or precipitating cause.

In the present study, the fatality rate in the first year of TB notification was $17.5 \%$ (4.1\% died before
TB notification and $13.4 \%$ died within 1 year after TB notification). This is much higher than rates reported earlier in Europe $\left(7.8 \%^{\circ}\right)$ and England and Wales $\left(8.4 \%^{10}\right)$, but similar to rates reported more recently in Taiwan $\left(16.5 \%{ }^{11}\right)$. This is probably a reflection of differences among patient profiles in these regions, especially age and the associated co-morbidities. In the present study, $47 \%$ of patients with TB were aged $\geq 60$ years (Table 1), whereas in the studies in Europe and the United Kingdom only $24.3 \%{ }^{9}$ and $17.9 \%{ }^{10}$ of the patients with TB were cohort aged $\geq 60$ years.

Our finding that $4.1 \%$ of $\mathrm{TB}$ cases were notified after death is similar to rates reported in Taiwan in $2006\left(4.0 \%{ }^{12}\right)$ and in the US in the $1980 \mathrm{~s}\left(5.1 \%^{13}\right.$ and $3.9 \%{ }^{14}$ ). In all of these reports, advanced age was a consistent observation for this extreme form of delayed diagnosis. As expected from the relatively short turnover time for sputum TB smear tests and CXRs, sputum TB smear negative, and CXR unknown or not done were important risk factors for TB notified after death. The strong association between these cases and positive sputum TB culture might be explained by the fact that the sputum TB culture was the primary method of TB diagnosis, unless a diagnosis had already been made during autopsy.

Our findings that drug abusers have a higher 
chance of TB notification after death is in line with an earlier study that suggested such patients have difficulty completing medical evaluations. ${ }^{15}$ Drug abusers might be less aware of their TB symptoms because of the effects of the drugs taken, such as opiate suppression of the cough reflex.

Female sex was also an independent factor in the current study, similar to a previous study in Taiwan. ${ }^{11}$ This is expected, because there is a higher proportion of women among the geriatric population ${ }^{16}$ and among residents of $\mathrm{OAH}^{17}$ owing to their longer life expectancy and because conservative treatment is more frequently selected by these elderly female patients or their guardians. Patients with terminal conditions might have an advance care directive against resuscitation or investigation. An incorrect provisional diagnosis might also result from the readiness to accept a diagnosis of advanced disseminated malignancy in a patient with such an advance care directive. As lung cancer patients usually had CXR and sputum samples taken in their initial diagnostic investigation, coexisting TB could be discovered early. In addition, most lung cancer patients were diagnosed at an advanced stage and usually died within the first year after presentation. ${ }^{18}$

In our study, TB-related death occurred shortly before or after TB treatment was started, in line with findings from studies in Taiwan, ${ }^{19}$ the US, ${ }^{20}$ and Russia $^{21}$ reporting a median time of 3 to 7 weeks from diagnosis or notification of $\mathrm{TB}$ to death. A study in Canada showed that a delay in TB treatment increased risk of death $(\mathrm{aOR}=3.3 ; 95 \%$ confidence interval $=1.7-6.2$ ) and intensive care unit admission $(\mathrm{aOR}=16.8 ; \quad 95 \% \quad$ confidence interval $=2-144) .{ }^{22}$ Another study of hospitalised patients with TB also showed that late TB treatment guided by conventional TB culture was associated with a higher mortality than for treatment guided by polymerase chain reaction (PCR), liquid culture, positive histological findings or typical clinico-radiological manifestation. ${ }^{23}$ In settings with a high human immunodeficiency virus prevalence, the WHO advocates early empirical TB treatment based on clinical and radiological criteria in patients strongly suspected as having TB but with sputum TB smear negative, because this can improve survival. ${ }^{24,25}$

Although a timely diagnosis might not avert most non-TB-related deaths, early treatment could reduce the institutional transmission risk, because $42 \%$ of patients with TB were living in OAHs in the current study. The prevalence of active TB in OAHs has been estimated to be as high as 669 per 100000 person-years in Hong Kong. ${ }^{26}$ The majority of patients in the present study did not have a positive sputum TB smear; however, a representative sputum sample might have been difficult to obtain from patients living in OAHs. That $73 \%$ of these patients had a positive sputum TB culture suggests that there was a sufficient degree of suspicion, either clinical or radiological, for initiation of bacteriological sampling. In total, 54 out of 211 patients who died before TB notification were recorded to have 'pneumonia unspecified' or 'respiratory disease' as the main cause of death. Past studies have shown that negative TB smear contributed to around $17 \%$ of TB transmission in San Francisco ${ }^{27}$ and Vancouver ${ }^{28}$ and even $30 \%$ in China. ${ }^{29}$ Thus, rapid diagnosis with effective isolation and early treatment can reduce transmission and even mortality. Sputum induction ${ }^{30}$ or gastric aspiration ${ }^{31}$ would improve specimen collection. However, in view of the infection risk, these bio-aerosol generating procedures would preferentially be performed in a negative pressure room with effective personal protective equipment as stipulated by the Institutional Infection Control Guidelines. Real-time PCR diagnostic tests such as Xpert ${ }^{\circledR}$ MTB/RIF assay ${ }^{32}$ may also be valuable, either as a primary diagnostic test or as an add-on test in patients previously found to be TB smear negative, to avoid the long turnover time for bacteriological cultures. In a study in Hong Kong, ${ }^{33}$ Xpert ${ }^{\circledR}$ MTB/ RIF assay was found to be a highly cost-effective strategy for TB diagnosis in terms of quality-adjusted life-years gained and lower first year mortality rate.

Higher mortality among patients with TB aged $\geq 80$ years is a consistent finding among different TB programmes. ${ }^{34}$ The present study also found frequently missed diagnosis of $\mathrm{TB}$ and excessive mortality among patients aged $\geq 80$ years who were frequently institutionalised and had multiple comorbidities. A high index of suspicion and rapid diagnostic tools are necessary to reduce both mortality and transmission risk in a rapidly ageing population, in order to meet the WHO End TB 2035 target of a $95 \%$ reduction in TB mortality rate compared with the 2015 rate. ${ }^{35}$

This study shares an important limitation with other retrospective studies. The clinical data in this cohort were constructed from a database of the preassembled 'TB programme record form' which was not specifically designed for this study. Therefore, not all pertinent risk factors were identified and recorded. As this is a population-wide database, many health care professionals were involved and the measurement of risk factors and outcomes is less accurate and less consistent than a prospective study. Nonetheless, data from the TB programme record form have been used in previous studies on patients with $\mathrm{TB}^{6}$ and elderly patients with $\mathrm{TB}^{7}$ and were included for comparison in this study.

\section{Conclusions}

This study was a collaborative effort between the Hospital Authority and the Department of Health, and a database was compiled for all patients with TB treated in the public or the private sector. This 
study provides insight into the mortality of patients with TB and the risk factors associated with a delay in TB diagnosis. These factors include novel patient factors such as female sex, living in OAHs, advance care directives refusing further investigation or resuscitation, and drug abuse. Additional factors include lack of a representative sputum sample. which could be mitigated by sputum induction or gastric aspiration, and the relative insensitivity of sputum TB smear and long turnover time for conventional TB culture, which could be mitigated by using of real-time PCR tests. Information generated by this study will help frontline clinicians to be better aware of this important infectious disease among elderly people. Hopefully, more resources will be allocated to promote rapid diagnosis of $\mathrm{TB}$ for patients in high-risk scenarios in Hong Kong.

\section{Acknowledgement}

The authors would likely to thank the Nursing and General Grade staff in Department of Health and Hospital Authority for their assistance in collection and compilation of the demographical, clinical and laboratory data for this study.

\section{Author contributions}

Concept or design: ECC Leung, CC Leung, CK Chan, KC Chang.

Acquisition of data: TYW Mok, KS Chan, KS Lau, CH Chau, WKS Yee, WM Leung, KF Au.

Analysis or interpretation of data: WS Law, SN Lee, LB Tai. Drafting of the article: ECC Leung, CC Leung, WM Leung, WS Law.

Critical revision for important intellectual content: All authors.

\section{Funding/support}

This research received no specific grant from any funding agency in the public, commercial, or not-for-profit sectors.

\section{Declaration}

The authors have no conflicts of interest to disclose.

\section{Ethical approval}

This study was approved by the Ethics Committee of the Department of Health and Ethics Committees of all hospital clusters from the Hospital Authority.

\section{References}

1. Demographic Statistics Section, Census and Statistics Department, Hong Kong SAR Government. Demographic Trends in Hong Kong 1981-2011. Available from: https:// www.statistics.gov.hk/pub/B1120017032012XXXXB0100. pdf Accessed 13 Jul 2018.

2. Tuberculosis and Chest Service, Department of Health, Hong Kong SAR Government. Annual Report 1981. Hong Kong: Department of Health, Hong Kong SAR Government; 1981.

3. Tuberculosis and Chest Service, Department of Health, Hong Kong SAR Government. Annual Report 2011. Available from: http://www.info.gov.hk/tb_chest/doc/
AnnualReport2011.pdf. Accessed 14 Jul 2018.

4. Leung CC, Yew WW, Chan CK, et al. Tuberculosis in older people: a retrospective and comparative study from Hong Kong. J Am Geriatr Soc 2002;50:1219-26.

5. World Health Organization. Definitions and reporting framework for tuberculosis-2013 revision. Geneva, Switzerland: World Health Organization; 2013.

6. Tam CM, Leung CC, Noertjojo K, Chan SL, Chan-Yeung $M$. Tuberculosis in Hong Kong-patient characteristics and treatment outcome. Hong Kong Med J 2003;9:83-90.

7. Chan-Yeung M, Noertjojo K, Tan J, Chan SL, Tam CM. Tuberculosis in the elderly in Hong Kong. Int J Tuberc Lung Dis 2002;6:771-9.

8. Centre for Health Protection, Department of Health, Hong Kong SAR Government. Notification \& death rate of tuberculosis (all forms), 1947-2017. Available from: https://www.chp.gov.hk/en/statistics/data/10/26/43/88. html. Accessed 20 Jul 2018.

9. Lefebvre N, Falzon D. Risk factors for death among tuberculosis cases: analysis of European surveillance data. Eur Respir J 2008;31:1256-60.

10. Crofts JP, Pebody R, Grant A, Watson JM, Abubakar I. Estimating tuberculosis case mortality in England and Wales, 2001-2002. Int J Tuberc Lung Dis 2008;12:308-13.

11. Wu YC, Lo HY, Yang SL, Chu DC, Chou P. Comparing the factors correlated with tuberculosis-specific and non-tuberculosis-specific deaths in different age groups among tuberculosis-related deaths in Taiwan. PLoS ONE 2015;10:e0118929.

12. Wu YC, Lo HY, Yang SL, Chou P. Factors correlated with tuberculosis reported after death. Int J Tuberc Lung Dis 2014;18:1485-90.

13. Rieder HL, Kelly GD, Bloch AB, Cauthen GM, Snider DE Jr. Tuberculosis diagnosed at death in the United States. Chest 1991;100:678-81.

14. DeRiemer K, Rudoy I, Schecter GF, Hopewell PC, Daley CL. The epidemiology of tuberculosis diagnosed after death in San Francisco, 1986-1995. Int J Tuberc Lung Dis 1999;3:488-93.

15. Deiss RG, Rodwell TC, Garfein RS. Tuberculosis and illicit drug use: review and update. Clin Infect Dis 2009;48:72-82.

16. Census and Statistics Department, Hong Kong SAR Government. Population by Age Group and Sex. Hong Kong Population By-Census Main Report. 2015. Available from: http://www.censtatd.gov.hk/hong_kong_statistics/ statistical_tables/index.jsp?charsetID $=1 \&$ tableID $=002$. Accessed 16 Mar 2016.

17. Luk JK, Chan FH, Pau MM, Yu C. Outreach geriatric service to private old age homes in Hong Kong West Clusters. J HK Geriatr Soc 2002;11:5-11.

18. Cancer Research UK. Lung cancer survival statistics. Available from: http://www.cancerresearchuk.org/healthprofessional/cancer-statistics/statistics-by-cancer-type/ lung-cancer/survival. Accessed 15 Mar 2016.

19. Lin CH, Lin CJ, Kuo YW, et al. Tuberculosis mortality: patient characteristics and causes. BMC Infect Dis 2014;14:5.

20. Oursler KK, Moore RD, Bishai WR, Harrington SM, Pope DS, Chaisson RE. Survival of patients with pulmonary tuberculosis: clinical and molecular epidemiologic factors. Clin Infect Dis 2002;34:752-9.

21. Mathew TA, Ovsyanikova TN, Shin SS, et al. Causes of death during tuberculosis treatment in Tomsk Oblast 
Russia. Int J Tuberc Lung Dis 2006;10:857-63.

22. Greenaway C, Menzies D, Fanning A, et al. Delay in diagnosis among hospitalized patients with active tuberculosis-predictors and outcomes. Am J Respir Crit Care Med 2002;165:927-33.

23. Lui G, Wong RY, Li F, et al. High mortality in adults hospitalized for active tuberculosis in a low HIV prevalence setting. PLoS One 2014;9:e92077.

24. Holtz TH, Kabera G, Mthiyane T, et al. Use of a WHOrecommended algorithm to reduce mortality in seriously ill patients with HIV infection and smear-negative pulmonary tuberculosis in South Africa: an observational cohort study. Lancet Infect Dis 2011;11:533-40.

25. Katagira W, Walter ND, Den Boon S, et al. Empiric TB treatment of severely ill patients with HIV and presumed pulmonary TB improves survival. J Acquir Immune Defic Syndr 2016;72:297-303.

26. Chan-Yeung M, Chan FH, Cheung AH, et al. Prevalence of tuberculous infection and active tuberculosis in old age homes in Hong Kong. J Am Geriatr Soc 2006;54:1334-40.

27. Behr MA, Warren SA, Salamon H, et al. Transmission of Mycobacterium tuberculosis from patients smear-negative for acid-fast bacilli. Lancet 1999;353:444-9.

28. Hernández-Garduño E, Cook V, Kunimoto D, Elwood RK, Black WA, FitzGerald JM. Transmission of tuberculosis from smear negative patients: a molecular epidemiology study. Thorax 2004;59:286-90.
29. Yang C, Shen X, Peng Y, et al. Transmission of Mycobacterium tuberculosis in China; a populationbased molecular epidemiologic study. Clin Infect Dis 2015;61:219-27.

30. Chang KC, Leung CC, Yew WW, Tam CM. Supervised and induced sputum among patients with smear-negative pulmonary tuberculosis. Eur Respir J 2008;31:1085-90.

31. Brown M, Varia H, Bassett P, Davidson RN, Wall R, Pasvol G. Prospective study of sputum induction, gastric washing, and bronchoalveolar lavage for the diagnosis of pulmonary tuberculosis in patients who are unable to expectorate. Clin Infect Dis 2007;44:1415-20.

32. Steingart KR, Schiller I, Horne DJ, Pai M, Boehme CC, Dendukuri N. Xpert ${ }^{\circledR}$ MTB/RIF assay for pulmonary tuberculosis and rifampicin resistance in adults. Cochrane Database Syst Rev 2014;(1):CD009593.

33. You JH, Lui G, Kam KM, Lee NL. Cost-effectiveness analysis of the Xpert MTB/RIF assay for rapid diagnosis of suspected tuberculosis in an intermediate burden area. J Infect 2015;70:409-14.

34. Waitt CJ, Squire SB. A systematic review of risk factors for death in adults during and after tuberculosis treatment. Int J Tuberc Lung Dis 2011;15:871-85.

35. World Health Organization. Implementing the end TB strategy: the essentials. Available from: http://www.who. int/tb/publications/2015/The_Essentials_to_End_TB/en/. Accessed 3 May 2017. 